\title{
Samarbeider om å forebygge trykksår
}

Trykksår kan medføre redusert livskvalitet og dårligere søvn, smerter og økt sykelighet og dødelighet. Derfor er det viktig med forebyggende tiltak, slik at trykksår ikke oppstår.

\section{FORFATTERE}

Edda Johansen

Førsteamanuensis og sykepleier

Høgskolen i Sørøst-Norge og Vestre Viken HF

Hanne Juritzen

Kvalitetssjef

Vestre Viken HF

Bente Monsen

Spesialrådgiver

Vestre Viken HF

Eva Engebrigtsen

Palliativ sykepleier

Vestre Viken HF

Linda Bakken

Førsteamanuensis

Høgskolen i Sørøst-Norge

\section{NøKKELORD}

Trykksår, Kvalitetsforbedring, Forskning

\section{HOVEDBUDSKAP}

Samarbeidet mellom helseforetak og høgskole har gjort at funn fra forskning raskt kan implementeres i det kontinuerlige forbedringsarbeidet. Resultatet er bedre rutiner for identifisering av risikopasienter, tilgang til hensiktsmessige madrasser og kunnskapsbaserte behandlingsplaner. I tillegg har de ansatte bedre kunnskap om og økt oppmerksomhet på trykksår.

Ifølge National Pressure Ulcer Advisory Panel / European Pressure Ulcer Advisory Panel kan trykksår defineres som

«en avgrenset skade på huden og/eller det underliggende vev, vanligvis over et benfremspring, som er et resultat av trykk eller trykk i kombinasjon med skjærende krefter. Flere medvirkende faktorer er også assosiert med trykksår; betydningen av disse er ennå ikke belyst» (1). 


\section{KLASSIFISERING}

Omfanget av hud- og vevsskade - altså graden av vevstap - ved trykksår beskrives ved hjelp av et klassifiseringssystem med fire kategorier samt ikke-klassifiserbare trykksår (ukjent dybde) og trykksår med mistenkt dyp vevsskade (ukjent dybde) (1). Klassifiseringssystemet bør brukes i forskning og kvalitetsarbeid sammen med en beskrivelse av hvor på kroppen trykksårene befinner seg (1).

Kategori 1-trykksår er intakt hud med rødhet som ikke blekner ved trykk, vanligvis over et benfremspring (1). I Vestre Viken HF (VVHF) har vi jobbet spesielt med å oppdage og iverksette tiltak hos pasienter med kategori 1-trykksår fordi huden er intakt, og det er mulig å reversere skadene.

Ettersom det kan være vanskelig å skille mellom trykksår og rødhet i huden forårsaket av inkontinensassosiert dermatitt (IAD) (2), har vi også lagt vekt på å bevisstgjøre oss forskjellene, i og med at tilstandene krever ulike tiltak for forebygging og behandling.

\section{UTBREDELSE}

Til tross for at de fleste trykksår kan forebygges, har det vist seg at 15-54 prosent av pasientene ved norske sykehus har trykksår $(3,4,5)$. Mange av sårene er på heler og korsbenet $(3,4,6)$.

\section{«15-54 prosent av pasientene ved norske sykehus har trykksår.»}

Trykksår kan medføre redusert livskvalitet og dårligere søvn, smerter og økt sykelighet og dødelighet, i tillegg til at det kan utgjøre en stor kostnad for samfunnet (7). Derfor er det viktig med forebyggende tiltak, slik at trykksår ikke oppstår.

\section{MÅLE FOR Å FOREBYGGE}

Et samarbeid mellom VVHF og Høgskolen i Sørøst-Norge (HSN) ble satt i gang i 2011 av forskere fra Norge og Irland (Royal College of Surgeons, RCSI), som ønsket å kartlegge og sammenlikne forekomsten av trykksår i Norge og Irland, ettersom praksis for forebygging var ulik i disse landene (8). Dette ble starten på et langvarig samarbeid omkring forskning (prevalensundersøkelser) og kvalitetsforbedring på området trykksår.

Vi kan oppnå trygge tjenester når vi kombinerer forskning, kunnskapsbasert praksis og forbedringsarbeid (9). Ifølge Pasientsikkerhetsprogrammet (10) kan trykksår forebygges gjennom enkle grep; se tiltakspakken fra programmet i figur 1. 


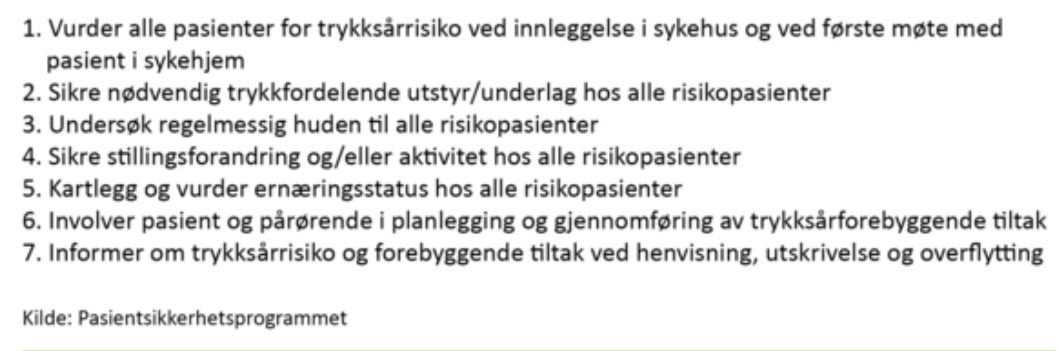

\section{PREVALENSUNDERS $\varnothing$ KELSER}

For stadig å bli bedre må en registrere og dokumentere trykksår og bruke resultatene til kvalitetsforbedring. I VVHF måles det ved mange sengeposter antall dager mellom hvert nyoppståtte trykksår. Mange registrerer hvilken kategori såret er, og hvor på kroppen det er. I tillegg måles årlig prevalens ved alle sengeposter.

Ved å kartlegge praksis for forebygging og utbredelse av trykksår som har oppstått i egen institusjon, kan en undersøke om innsatsen har gitt forbedringer. Gjentatte målinger, såkalte prevalensunders $\varnothing$ kelser, kan underst $\varnothing$ tte et kontinuerlig forbedringsarbeid ved at de frembringer pålitelige resultater om dagens praksis og uheldige hendelser.

VVHF har hatt positive erfaringer med de gjentatte prevalensunders $\varnothing$ kelsene som kartlegger forekomsten av trykksår og dokumentert forebygging, men anerkjenner likevel at metoden har visse begrensninger fordi den bare gir et her-og-nå-bilde av situasjonen.

\section{DATAINNSAMLING}

En prevalensundersøkelse registrerer alle trykksår på den aktuelle dagen, både de som har oppstått i foretaket, og trykksårene pasienten hadde ved innleggelse. For å få reelle tall på antallet trykksår oppstått i foretaket må en se på antallet trykksår en fant på undersøkelsesdagen og trekke fra de sårene pasientene hadde ved innleggelse. Dette krever imidlertid at helsepersonell har oppdaget og dokumentert trykksår hos pasientene ved innleggelse.

For å samle inn pålitelige data hadde alle fått opplæring, de gikk to og to sammen, og ingen samlet data på egen avdeling.

\section{«Gjentatte prevalensunders $\emptyset$ kelser kan skape en kultur for pasientsikkerhet og forbedring.»}


I VVHF kommer prevalensunders $\emptyset$ kelsene i tillegg til kontinuerlige insidensmålinger (antallet dager mellom oppståtte trykksår, som beskrevet over) ved flere sengeposter i VVHF som et ledd $\mathrm{i}$ et kontinuerlig forbedringsarbeid inspirert av pasientsikkerhetsprogrammet. Samlet gir resultatene viktige data til det kontinuerlige forbedringsarbeidet.

\section{RESULTATER}

Til nå har det blitt gjennomført tre prevalensundersøkelser i VVHF, i 2012, 2016 og 2017. Den første studien (2012) ble gjennomført ved kun ett av sykehusene, Drammen.

Unders $\emptyset$ kelsen fra 2012 frembrakte konkrete tall på forekomsten av trykksår, og avdekket at få pasienter hadde dokumentert risikovurdering, og at behandlingsplaner for forebygging ikke nødvendigvis var iverksatt hos risikopasienter (3). Det viste seg også at standardmadrassene ikke holdt god nok kvalitet, noe VVHF ikke hadde hatt forskningstall på tidligere (3).

Målet med kunnskapen fra prevalensundersøkelsene er å redusere faren for gjentakelser, noe som krever kunnskap, systemer og rammer som muliggjør forbedringsarbeidet (9).

Studien fra 2012 ga startskuddet for et forbedringsarbeid for å etablere gode rutiner for identifisering av risikopasienter, øke kunnskapen om trykksår blant ansatte samt sikre tilgang til hensiktsmessige madrasser og kunnskapsbaserte behandlingsplaner for forebygging. Når resultatene fra forbedringsarbeidet kombineres med kunnskap, kan det gi både motivasjon og gode resultater.

\section{BEDRE RUTINER}

Her beskriver vi de endringene som er iverksatt for å sikre trygge og kunnskapsbaserte tjenester. Ettersom det fortsatt arbeides med resultatene fra unders $\varnothing$ kelsene i 2016 og 2017, vil flere forbedringer iverksettes som følge av disse studiene; disse blir ikke presentert her.

\section{RISIKOVURDERING}

For å lykkes med å forebygge trykksår må en identifisere de pasientene som har risiko for å få trykksår. Samtidig med den første studien i 2012 var en av forskerne (EJ) engasjert i pasientsikkerhetsprogrammets ekspertgruppe for forebygging av trykksår. Ekspertgruppen skulle gi anbefalinger til en tiltakspakke for forebygging, inkludert praksis for risikovurdering.

\section{«For å lykkes med å forebygge trykksår må en identifisere de pasientene som har risiko for å få trykksår.»}

Ettersom mobilitets- og aktivitetsbegrensninger er en nødvendig betingelse for å få trykksår (1) og det ikke var bevist gjennom forskning at risikovurderingsskjemaer var bedre enn klinisk vurdering $(11,12)$, foreslo forskeren en strukturert tilnærming til risikovurdering basert på immobilitet og klinisk vurdering som et alternativ til bruk av ulike typer skjemaer (10 , 13) (se figur 2). 
Spørsmålene bygger på anbefalinger fra National Pressure Ulcer Advisory Panel / European Pressure Ulcer Advisory Panel (1), det ikke-numeriske Ramstadius-skjemaet (14) og funn fra egen forskning omkring risikovurdering (8).

\title{
HUDINSPEKSJON
}

Spørsmålene krever at en gjør en grundig hudinspeksjon hos alle pasienter som innlegges, for å unders $\emptyset$ ke om pasienten allerede har trykksår. Finner en at pasienten har trykksår, skal dette dokumenteres, tiltakspakken for forebygging av nye trykksår iverksettes, og pasienten skal sikres en sårbehandlingsplan for trykksåret.

Figur 2: Risikovurdering basert på tre spørsmål

\section{Risikovurdering med tre spørsmål:}

\author{
1) Har pasienten trykksår ved innleggelse/overflytting? \\ 2) Har pasienten behov for hjelp til å endre stilling i seng eller stol? \\ 3) Vurderer du det som sannsynlig at pasienten kan få trykksår under innleggelsen? \\ Hvis det svares ja på minst ett av spørsmålene, er pasienten i risikogruppen for trykksår.
}

For å sikre at pasienter blir risikovurdert ved innkomst, valgte VVHF å implementere disse tre spørsmålene i DIPS i det de har valgt å kalle «sjekkliste pasientsikkerhet». Sjekklisten omfatter flere pasientsikkerhetsområder i tillegg til trykksår, som for eksempel samstemming av legemiddellister, SVK-relaterte infeksjoner og kateter-indiserte UVI (15).

Det er sykepleiere som er ansvarlige for å vurdere pasienters risiko for trykksår og opprette behandlingsplaner i DIPS (15). Målet er at sjekklisten opprettes i akuttmottaket og følges opp på sengepostene, noe som innebærer at en raskt får identifisert om pasienter har, eller har risiko for å få, trykksår.

\section{ELEKTRONISK SYSTEM}

Erfaringer fra prevalensunders $\varnothing$ kelsene tilsier at alle pasienter må unders $\varnothing$ kes for trykksår, slik Pasientsikkerhetsprogrammet (10) og den lokale prosedyren (15) krever, fordi det har blitt oppdaget trykksår hos mobile pasienter og hos pasienter som selv ikke var klare over at de hadde det.

Det jobbes med å få elektroniske rapporter knyttet til sjekklisten, slik at den etterleves, kan følges opp gjennom målinger og brukes til forbedringsarbeid. Foreløpig gjennomføres manuelle målinger av etterlevelse av sjekklisten kun ved ett sykehus (Ringerike), der fagutviklingssykepleiere foretar dokumentanalyser (DIPS og avviksmeldinger) av hver tredje pasient minst hver tredje måned (16).

\section{«I 2012 ble det dokumentert risikovurdering hos kun 8 prosent av pasientene.»}


Undersøkelsene kan vise hvorvidt pasienter blir risikovurdert, og hvorvidt risikopasienter får behandlingsplan i DIPS (16). I påvente av et elektronisk system for å hente data fra sjekklisten gjøres det kvalitetsmålinger fire ganger årlig kun ved ett av sykehusene.

I 2012 ble det dokumentert risikovurdering hos kun 8 prosent av pasientene (3), mot over 50 prosent i prevalensunders $\varnothing$ kelsen i 2016 , noe som kan tyde på at forbedringene sikrer at flere pasienter blir risikovurdert ved innleggelse.

Ettersom risikovurderingen med de tre spørsmålene krever at en gjør en grundig hudvurdering for å se om pasienter har trykksår, noe som vil gjenspeile seg $\mathrm{i}$ dokumentasjonen, kan en anta at troverdigheten av prevalensunders $\varnothing$ kelsene vil $\varnothing k e$ sammen med forbedret dokumentasjon.

\section{MANGELFULL KVALITET}

Studien fra 2012 viste at en stor andel av madrassene ikke holdt god nok standard, og at svært få vekselstrykkmadrasser var i bruk (3). Videre gjennomgang etter undersøkelsen avdekket mangler ved datomerking og utskifting av madrassene, noe som kan ha bidratt til at utdaterte madrasser fortsatt var i bruk.

Funnene ble presentert for foretaksledelsen, hvor det ble fremmet et forslag om å bevilge midler til nye madrasser i Vestre Viken. Dette resulterte i at de somatiske sykehusene i VVHF byttet ut gamle standardmadrasser med nye madrasser med bedre trykkfordelende effekt.

For å sikre jevnlig oppdatering av standardmadrasser ble det laget et nytt system for datomerking og utskifting, som blir tatt hånd om av Klinikk for intern service. I tillegg ble det etablert en avtale om leie av vekselstrykkmadrasser til enkelte pasientgrupper som har spesiell risiko for å få trykksår.

Et langsiktig mål er å ha kun to typer madrasser i foretaket, det vil si en standardmadrass som egner seg bedre for risikopasienter (oppdelt skum eller madrass med viskoelastisk materiale), og tilgang til vekselstrykkmadrasser for høyrisikopasienter. Dette vil gjøre det enkelt for ansatte å sikre riktig madrass. Imidlertid vil en fortsatt måtte sette av tid til å bytte til vekselstrykkmadrasser for høyrisikopasienter.

\section{RETT MADRASS}

Før 2012 hadde VVHF mange ulike typer madrasser i omløp, og det var ingen formell prosedyre for å sikre rett madrass til rett pasient. Det var sengepostspesifikke avtaler og dermed ulik tilgang til og praksis for bruk av blant annet skummadrasser, viskoelastiske madrasser (Tempur) og vekselstrykkmadrasser i foretaket.

\section{«Det var ingen formell prosedyre for å sikre rett madrass til rett pasient.»}


Figur 3: Algoritme for valg av riktig madrass

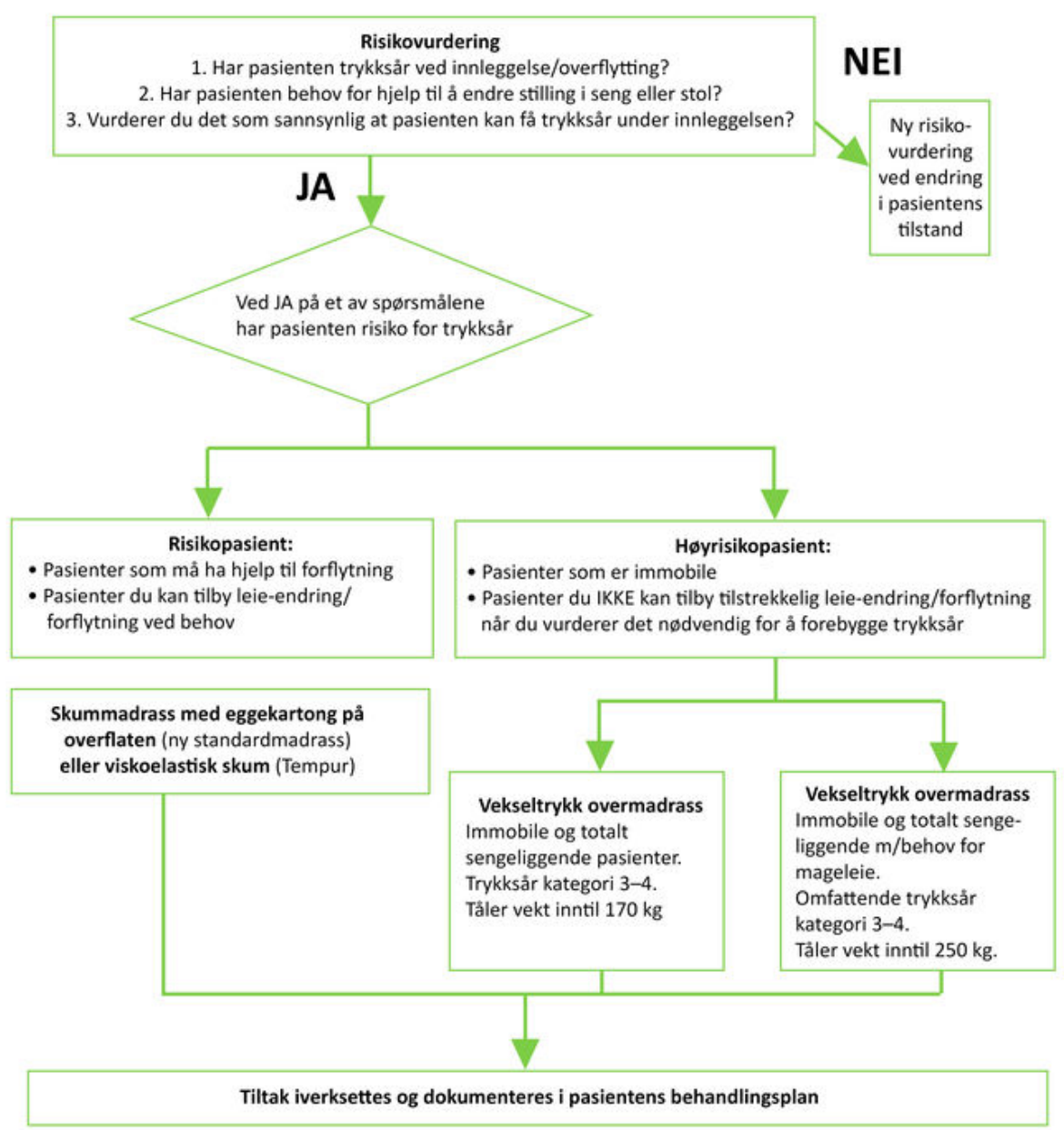

Kontraindikasjon:

ryggmargskade, ustabil cervicalcolumna

eller bekkenfractur

Prosedyren og algoritmen, sammen med avtalen om leie av vekselstrykkmadrasser, har bidratt til mindre variasjon i bruken av ulike typer madrasser i foretaket. Algoritmen vil måtte justeres dersom VVHF velger en annen type standardmadrass, for eksempel oppdelt skum eller madrass med viskoelastisk materiale, fremfor dagens standardmadrass.

\section{MEDIEDEKNING}

Den manglende kvaliteten på standardmadrassene og det faktum at VVHF raskt tok grep og lagde en plan for å skifte dem ut, fikk mye mediedekning. Kvalitetsavdelingen og HSN sto sammen om å presentere resultater og konsekvenser av unders $\varnothing$ kelsen $(17,18,19)$.

Selv om få pasienter deltok i prevalensunders $\varnothing$ kelsen i $2012(n=59)(3)$, har forbedringene som studien resulterte $i$, kommet mange pasienter til nytte, ikke minst fordi kunnskapen fra studien raskt ble implementert i praksis.

\section{BEHANDLINGSPLANER}


I etterkant av undersøkelsen i 2012 kom klinikere og forskere i samarbeid frem til at for å lykkes med å sikre risikopasienter forebyggende behandlingsplaner må det foreligge en standard behandlingsplan i DIPS. En veiledende behandlingsplan for forebygging av trykksår, basert på nyeste evidens, ble derfor utviklet og implementert i DIPS.

Sammen med ny praksis for risikovurdering, nye dokumenter i DIPS, nye standardmadrasser, algoritme for valg av rett madrass og tilgang til utstyr i form av vekselstrykkmadrasser var målet å sikre risikopasienter nødvendige forebyggende tiltak, anbefalt av Pasientsikkerhetsprogrammet (10) (se figur 1).

\section{AVSLUTNING}

Pasientsikkerhet gjennom gode og trygge tjenester er gitt nasjonal og internasjonal oppmerksomhet $(9,20)$ og er høyt prioritert i VVHF. Samarbeidet mellom VVHF og HSN, der en har kombinert forskning, forbedringstiltak og kunnskapsbasert praksis, har vist at en raskt kan implementere ny kunnskap og øke pasientsikkerheten lokalt.

Dette samarbeidet startet som et forskningsprosjekt initiert av norske (HSN) og irske (RCSI) forskere og dreide seg opprinnelig om trykksår, men har utviklet seg til å bli et langvarig samarbeid med mål om å skaffe verdifull kunnskap til støtte for kvalitetsutvikling og trygge tjenester.

\section{«Dynamikken mellom de ansatte i helseforetaket og høgskolen har vært avgjørende for samarbeidet.»}

Dynamikken mellom de ansatte i helseforetaket og høgskolen har vært avgjørende for samarbeidet. Et slikt samarbeid trenger ikke å begrense seg til forebygging av trykksår, men kan videreutvikles til å omfatte også andre områder eller temaer.

\section{REFERANSER}

1. National Pressure Ulcer Advisory Panel, European Pressure Ulcer Advisory Panel, Pan Pacific Pressure Injury Alliance. Prevention and treatment of pressure ulcers: quick reference guide. Osborne Park, Australia: Cambridge Media; 2014.

2. Beeckman D. A decade of research on incontinence-associated dermatitis (IAD): evidence, knowledge gaps and next steps. J Tissue Viability. 2017;26(1):47-56.

3. Moore Z, Johansen E, van Etten M, Strapp H, Solbakken T, Smith BE, et al. Pressure ulcer prevalence and prevention practices: a cross-sectional comparative survey in Norway and Ireland. J Wound Care. 2015;24(8):333-9.

4. Bredesen IM, Bjøro K, Gunningberg L, Hofoss D. The prevalence, prevention and multilevel variance of pressure ulcers in Norwegian hospitals: a cross-sectional study. Int J Nurs Stud. 2015;52(1):149-56

5. Bjøro K, Ribu L. Pilotstudie av trykksårprevalens i et norsk sykehus. Sykepleien Forskning 
6. Johansen E, Bakken LN, Moore Z. Pressure ulcer in Norway - a snapshot of pressure ulcer occurrence across various care sites and recommendations for improved preventive care. Healthcare (Basel). 2015;3(2):417-28.

7. Dealey C, Posnett J, Walker A. The cost of pressure ulcers in the United Kingdom. J Wound Care. 2012;21(6):261-4.

8. Johansen E, Moore Z, van Etten M, Strapp H. Pressure ulcer risk assessment and prevention: What difference does a risk scale make? A comparison between Norway and Ireland. Journal of Wound Care 2014;23(7):369-78.

9. Sosial- og helsedirektoratet. ... og bedre skal det bli! Nasjonal strategi for kvalitetsforbedring i Sosial- og helsetjenesten 2005-2015. Oslo: Sosial- og helsedirektoratet; 2005. IS-1162. Tilgjengelig fra:

https://helsedirektoratet.no/Lists/Publikasjoner/Attachments/233/Og-bedre-skal-det-bli-nasjonal-strategi-for-kvalitetsforbedring-i-sosial-og-helse tjenesten-2005-2015-IS-1162-bokmal.pdf (nedlastet 13.12.2017).

10. Pasientsikkerhetsprogrammet. I trygge hender 24-7 [internett]. Oslo:

Pasientsikkerhetsprogrammet; 21.12.2010 [oppdatert 28.09.2017; sitert 13.12.2017].

Tilgjengelig fra: http://www.pasientsikkerhetsprogrammet.no/

11. Webster J, Coleman K, Mudge A, Marquart L, Gardner G, Stankiewicz M, et al. Pressure ulcers: effectiveness of risk-assessment tools. A randomised controlled trial (the ulcer trial). BMJ Qual Saf. 2011;20(4):297-306.

12. Saleh $\mathrm{M}$, Anthony $\mathrm{D}$, Parboteeah $\mathrm{S}$. The impact of pressure ulcer risk assessment on patient outcomes among hospitalised patients. J Clin Nurs. 2009;18(13):1923-9.

13. Johansen E. The 3-risk approach to pressure ulcer assessment in Norway - safe or a risky business? Wounds UK. 2017;13(4):50-4. Tilgjengelig fra: http://www.wounds-uk.com/pdf/content_12061.pdf (nedlastet 18.12.2017).

14. Moore ZEH, Cowman S. Risk assessment tools for the prevention of pressure ulcers. Cochrane Database Syst Rev. 2014(2):Art.No.CD006471.

15. Bråten HE. VV sjekkliste pasientsikkerhet i DIPS - rutine for kartlegging [intern kvalitetshåndbok ved Vestre Viken HF]. Drammen: Vestre Viken HF; 2016.

16. Bråten HE. VV etterlevelse av sjekkliste pasientsikkerhet [intern kvalitetshåndbok ved Vestre Viken HF]. Drammen: Vestre Viken HF; 2016.

17. Torsøe M. Dårlige madrasser på norske sykehus gir liggesår [internett]. Forskning.no; 2014 [sitert 20.02.2015]. Tilgjengelig fra:

http://forskning.no/helse-helsetjeneste-helseadministrasjon/2014/10/madrassene-pa-norske-sykehus-er-darlige

18. Brendhagen K. Dårlige madrasser gir liggesår [internett]. Nrk.no; 2014 [sitert

06.09.2016]. Tilgjengelig fra: https://www.nrk.no/buskerud/darlige-madrasser-gir-liggesar-1.11987008

19. Mannsverk PT. Nye madrasser på sykehuset. Nrk.no; 2015 [sitert 06.09.2016].

Tilgjengelig fra: http://www.ringblad.no/nyheter/nye-madrasser-til-sykehuset/s/5-45-28622 
20. World Health Organization. Patient safety: making health care safer. Genève: WHO;

2017. Tilgjengelig fra: http://apps.who.int/iris/bitstream/10665/255507/1/WHO-HIS-SDS-2017.11-eng.pdf?ua=1 (nedlastet 27.07.2017). 